\title{
ESTIMATION OF TOTAL FLAVONOIDS CONTENT (TFC) AND ANTI OXIDANT ACTIVITIES OF METHANOLIC WHOLE PLANT EXTRACT OF BIOPHYTUM SENSITIVUM LINN
}

\author{
Kalita Pallab*, Barman Tapan K., Pal Tapas K., Kalita Ramen \\ NSHM Knowledge campus, Kolkata Group of institution, 124- B.L. Saha road, Kolkata-700053, West Bengal, India \\ *Corresponding Author's Contact no; 8961398508, Email: kalitapallab@gmail.com
}

\begin{abstract}
:
Biophytum sensitivum linn. (Oxalidaceae), is an important and widely used medicinal plant. Biophytum sensitivum linn. is used as a traditional folk medicine in ailments such as inflammation, arthritis, wounds, tumors and burns, gonorrhea, stomach ache, asthma, cough, degenerative joint disease, urinary calculi, diabetes, snake bite, amenorrhea and dysmenorrhea.. The total flavonoid content of methanolic whole plant extract of B. sensitivum (MEBS) was determined by using aluminium chloride colorimetric method. Flavonoid compounds were found to be $9.49 \mu \mathrm{g}$ of quercetin equivalent [QE] per mg of methanolic whole plant extract of Biophytum sensitivum. In this study phytochemical analysis of methanolic extract of B. sensitivum L. has indicated the presence of flavonoid. Since these compounds are of pharmacological interest, coupled with the use of this plant in traditional medicine, it prompted us to check B.sensitivum $L$. for possible antioxidant activity by DPPH scavenging activity and reducing power ability. The maximum percentage inhibition by DPPH method was found about 43.96 at concentration of $110.46 \mu \mathrm{g} / \mathrm{ml}$, when compared with Quercetin. The reducing capabilities were found to be in dose dependent manner.
\end{abstract}

Key words: Biophytum sensitivum, aluminium chloride, quercetin, DPPH.

\section{INTRODUCTION:}

For thousands of years mankind is using plant sources to alleviate or cure illness ${ }^{1}$. Novel chemical compounds synthesis from the plant active constituents, which are of potential use in medicine and other usefull application. Herbal remedies are popular remedies for diseases used by a vast vast majority of the world's population ${ }^{2}$. Herbal plants having many pharmacologically active compounds like flavonoids, alkaloids, tannin, steroids, glycosides, phenols, fixed oils, which is stored in their specific parts of leaves, bark, flowers, seed, fruits, root etc. ${ }^{3}$. Biophytum sensitivum (family- Oxalidaceae) having different pharmacological activities such as dengu,anticancer, antiinflammatory, chemoprotective, antidiabetic and wound healing activities of their different parts ${ }^{4-8}$.

There is an increased evidence for the participation of free radicals in the etiology of various diseases like cancer, diabetes, cardiovascular diseases, autoimmune disorders, neurodegenerative diseases, aging etc. A free radical is defined as any atom or molecule possessing unpaired electrons. Antioxidants are agents which scavenge the free radicals and prevent the damage caused by reactive oxygen species (ROS), reactive nitrogen species (RNS). ROS is composed of superoxide anion (O2·), hydroxyl (OH·), hydroperoxyl ( $\mathrm{OOH} \cdot$ ), peroxyl (ROO·), alkoxyl (RO·) radicals non free radicals are hydrogen peroxide $(\mathrm{H} 2 \mathrm{O} 2)$, hypochlorous acid ( $\mathrm{HOCl}$ ), ozone (O3) singlet oxygen (1O2). RNS are mainly nitric oxide (NO·), peroxynitrite (ONOO-) nitrogen dioxide (NO2). Antioxidants can greatly reduce the damage due to oxidants by neutralizing the free radicals before they can attack the cells prevent damage to lipids, proteins, enzymes, carbohydrates DNA. A wide range of antioxidants from both natural and synthetic origin has been proposed for use in the treatment of various human diseases 9 . Flavonoids are potent

antioxidants and have aroused considerable interest recently because of their potential beneficial effects on human health in fighting diseases. The capacity of flavonoids to act as antioxidants depends upon their molecular structure. The position of hydroxyl groups and other features in the chemical structure of flavonoids are important for their antioxidant and free radical scavenging activities. Quercetin, the most abundant dietary flavonol, is a potent antioxidant because it has all the right structural features for free radical scavenging activity ${ }^{10}$. Therefore, the objective of our present study is to determine the antioxidant and total flavonoid content of whole plant extract of Biophytum sensitivum using quercetin, Aluminium Chloride colorimetric method. In the study quercetin taking as a standard flavonoids.

\section{MATERIALS AND METHODS:}

\section{Plant material:}

Biophytum sensitivum were collected from the forest of Medinapur, WB. $30 \mathrm{~kg}$ of plant materials was identified taxonomically by expert taxonomist at the Botanical survey of India,Howrah, west Bengal, India. Voucher specimen of the plant at B.S.I. is 942 (dated 17-9-68) and the collected sample has been matched with the voucher specimen taxonomically and deposited in the institution herbarium for future reference.

\section{Chemicals:}

Quercetin, aluminium chloride, Diphenylpicryl hydrazine(DPPH), Trichloroacetic acid(TCA) and $\mathrm{FeCl} 3$.

DPPH was obtained from Hi media laboratories Pvt. Ltd. Mumbai. Aluminium chloride, TCA, FeCl3 were obtained from Merck, Mumbai, India; Quercetin was obtained from Sisco research laboratories Pvt. Ltd. (SRL) Mumbai, India. 
Preparation of extracts by using soxhlet extracting methods:

$100 \mathrm{~g}$ of whole plant material was taken in a soxhlet and $80 \%$ methanol was added up to 2 siphons that is up to $500 \mathrm{ml}$. The temperature is set to $700 \mathrm{C}$ and the extraction was carried out up to 5 hours. Then the extract obtained is filtered and concentrated at 700C. Dried extracts were kept in refrigerator and used for further study ${ }^{11}$.

Estimation of total flavonoid content Aluminium Chloride Colorimetric Method:

\section{Principle:}

Formation of acid stable complexes with the C-4 keto group and either the C-3 or C-5 hydroxyl group of flavones and flavonols in addition with aluminium chloride. Aluminium chloride also forms acid labile complexes with the ortho - dihydroxyl groups in the A- or B-ring of flavonoids. For building the calibration curve , quarcetin is used as a standard materials. Various concentrations of standard quarcetin solution were used to make a standard calibration curve ${ }^{10}$.

\section{Procedure:}

In this method, quercetin was used to make the calibration curve. $10 \mathrm{mg}$ of quercetin was dissolved in methanol and then diluted to $6.25,12.5,25,50,80$, and $100 \mu \mathrm{g} / \mathrm{ml}$. A calibration curve was made by measuring the absorbance of the dilutions at $415 \mathrm{~nm}$ ( $\lambda$ max of quercetin) with a Shimadzu UV-1800 spectrophotometer. Aluminium chloride, $1 \%$ and potassium acetate, $1 \mathrm{M}$ solutions were prepared $^{10,12,13}$.

\section{Stock Solution of Extracts:}

$100 \mathrm{mg}$ of the each extract was accurately weighed and transferred to $10 \mathrm{ml}$ volumetric flask and made up the volume with methanol.

\section{Preparation of Test Solutions:}

$0.5 \mathrm{ml}$ of each extract stock solution, $1.5 \mathrm{ml}$ methanol, 0.1 $\mathrm{ml}$ aluminium chloride, $0.1 \mathrm{ml}$ potassium acetate solution and $2.8 \mathrm{ml}$ distilled water were added and mixed well. Sample blank was prepared in similar way by replacing aluminium chloride with distilled water. Sample and sample blank of all four extracts were prepared and their absorbance was measured at $415 \mathrm{~nm}$. All prepared solutions were filtered through whatmann filter paper before measuring.

\section{ANTIOXIDANT ACTIVITY:}

In this study free radical scavenging activity of methanolic whole plant extract of Biophytum sensitivum was determined by in vitro assay models such as DPPH free radical, reducing ability. Quercetin was used as reference standard.

\section{DPPH radical scavenging activity:}

\section{Principle:}

DPPH radical is scavenged by antioxidants through the donation of proton forming the reduced DPPH. The color changes from purple to yellow after reduction, which can be quantified by its decrease of absorbance at wavelength $517 \mathrm{~nm}$. Radical scavenging activity increased with increasing percentage of the free radical inhibition. The degree of discoloration indicates the free radical scavenging potentials of the sample/antioxidant by their hydrogen donating ability. The electrons become paired off and solution loses colour stochiometrically depending on the number of electrons taken up ${ }^{9}$.

\section{Procedure:}

DPPH radical scavenging activity was measured using the method of Kiranmai et al.; with some modifications. $2 \mathrm{ml}$ of reaction mixture containing $1 \mathrm{ml}$ of DPPH $(100 \mu \mathrm{M}$ in methanol) $1 \mathrm{ml}$ of test solution, at various concentrations of the extract fractions was incubated at $37^{\circ} \mathrm{C}$ for $30 \mathrm{~min}$ absorbance of the resulting solution was measured at 517 nm using Beckman model DU-40 spectrophotometer. The percentage inhibition of DPPH radical was calculated by comparing the results of the test with those of the control (not treated with extract) using the following equation ${ }^{9,14}$ :

$$
\text { Percentage inhibition }=
$$

$(1-$ absorbance of test/absorbance of control $) \times 100$

\section{REDUCING ABILITY:}

\section{Principle:}

Like the antioxidant activity, the reducing power increased with increasing amount of the extract.when potassium ferricyanide react with ferric chloride in the present of anti oxidant, potassium ferrocyanide and ferrous chloride are found as a product. Presence of reducers causes the conversion of the $\mathrm{Fe} 3+/$ ferricyanide complex used in this method to the ferrous form ${ }^{14}$.

\section{Procedure:}

$1 \mathrm{ml}$ of different concentrations (25 to $900 \mu \mathrm{g} / \mathrm{ml}$ ) of the extract fractions was mixed with potassium ferricyanide (2.5 ml, 1\%) $2.5 \mathrm{ml}$ of phosphate buffer ( $\mathrm{pH} \mathrm{6.6).} \mathrm{The}$ mixture was incubated at $50^{\circ} \mathrm{C}$ for $20 \mathrm{~min}$. $2.5 \mathrm{ml} \mathrm{TCA}$ $(10 \%)$ was added to it and centrifuged at $3000 \mathrm{rpm}$ for 10 min. $2.5 \mathrm{ml}$ of supernatant was taken and $2.5 \mathrm{ml}$ water and $0.5 \mathrm{ml} \mathrm{FeCl} 3(0.1 \%)$ were added to it. The absorbance was measured at $700 \mathrm{~nm}$. Higher absorbance of the reaction mixture indicated higher reducing power ${ }^{14-16}$.

\section{RESULTS AND DISCUSSION:}

\section{Determination of Total flavonoid content:}

To perform the calculations of total flavonoid content in the studied plant using Kiranmai et al., method, a standard curve is needed which is obtained from a series of different quercetin concentrations.

Table 1: Results of calibration curve

\begin{tabular}{|l|c|c|}
\hline $\begin{array}{l}\text { S. } \\
\text { N. }\end{array}$ & $\begin{array}{c}\text { Concentration of plant } \\
\text { Extract }(\mu \mathrm{g} / \mathrm{ml})\end{array}$ & $\begin{array}{l}\text { Absorbance } \\
\text { at } 415 \mathrm{~nm}\end{array}$ \\
\hline 1. & 403 & 0.094 \\
\hline 2. & 1007 & 0.243 \\
\hline
\end{tabular}




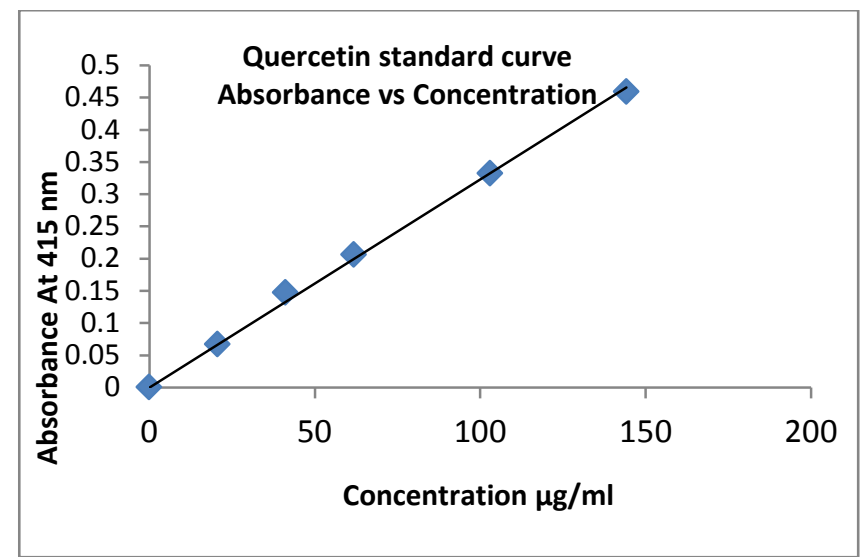

Figure 1: Quercetin standard curve
Concentration values of extracts were obtained from Quercetin standard curve, by interpolating to the $\mathrm{X}$ - axis. TFC was calculated by using the following formula ${ }^{18}$

$$
\mathbf{T F C}=\frac{R \times D . F \times V \times 100}{W}
$$

Where,

$\mathrm{R}$ - Result obtained from the standard curve

D.F - Dilution factor

V - Volume of stock Solution

100 - For $100 \mathrm{~g}$ dried plant

W - Weight of plant used in the experiment

Table 2: \% yield and total flavonoid content of extract

\begin{tabular}{|l|c|c|}
\hline \multicolumn{1}{|c|}{ Extract } & Yield $(\% \mathrm{w} / \mathrm{w})$ & $\begin{array}{c}\text { TFC } \\
(\mu \mathrm{g} \text { of QE/mg of extract) }\end{array}$ \\
\hline $\begin{array}{l}\text { Methanolic root extract of } \\
\text { Clerodendrum infortunatum }\end{array}$ & 7 & 9.49 \\
\hline
\end{tabular}

Total flavonoid content of the extracts is given in table 6 . The soxhlet method gave the yield of crude extract $7 \% \mathrm{w} / \mathrm{w}$.

Table 3: DPPH Radical Scavenging Activity

\begin{tabular}{|l|c|c|c|}
\hline \multirow{2}{*}{ Sr. no. } & $\begin{array}{c}\text { Concentration } \\
(\mu \mathrm{g} / \mathrm{ml})\end{array}$ & \multicolumn{2}{|c|}{ Absorbance at 517 $\mathrm{nm}$} \\
\cline { 3 - 4 } & 22.08 & MEBS & QUERCETIN \\
\hline 1. & 44.16 & 3.64 & 2.968 \\
\hline 2. & 55.20 & 3.54 & 2.392 \\
\hline 3. & 77.28 & 3.29 & 1.911 \\
\hline 4. & 110.40 & 2.88 & 1.252 \\
\hline 5. & 2.135 & 0.681 \\
\hline
\end{tabular}

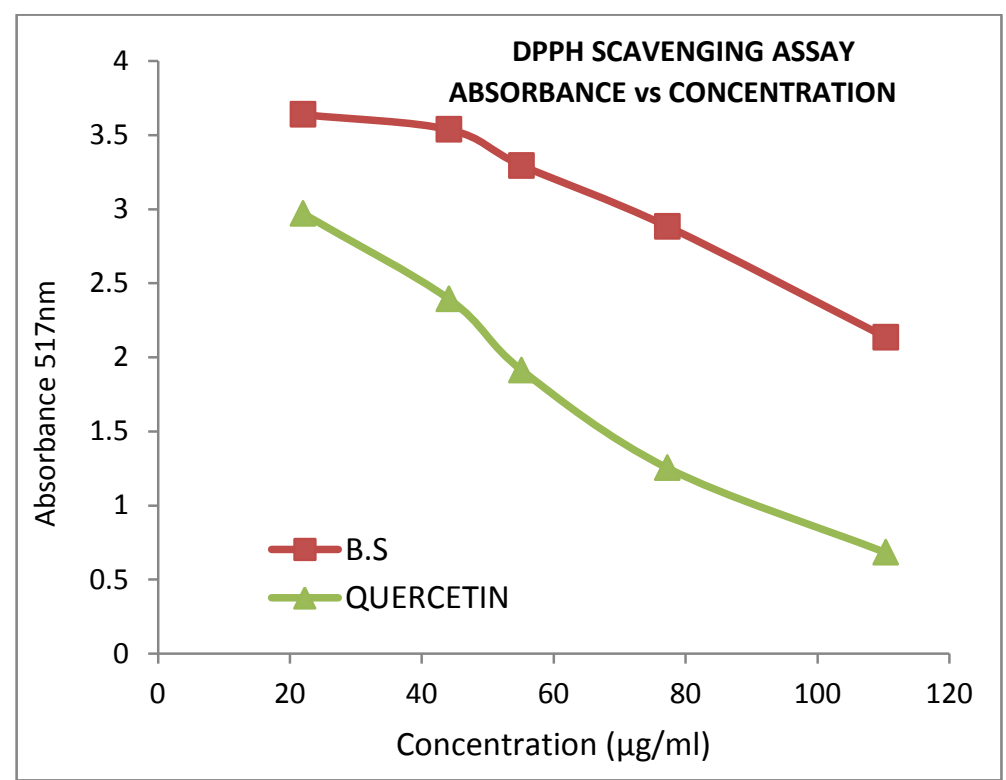

Figure 2: DPPH scavenging assay of methanolic whole plant extract of B.S. with respect to standard Quercetin 
Table 4: Evaluation of DPPH free-radical scavenging activity of methanolic whole plant extract of B.S. with respect of standard Quercetin

\begin{tabular}{|c|c|c|c|}
\hline \multirow{2}{*}{ Sr. no } & \multirow{2}{*}{ Concentration $(\mu \mathrm{g} / \mathrm{ml})$} & \multicolumn{2}{|c|}{ \% of inhibition } \\
\cline { 3 - 4 } & & MEBS & QUERCETIN \\
\hline 1. & 22.08 & 4.51 & 22.10 \\
\hline 2. & 44.16 & 7.17 & 37.22 \\
\hline 3. & 55.20 & 13.54 & 49.84 \\
\hline 4. & 77.28 & 24.33 & 67.14 \\
\hline 5. & 110.46 & 43.96 & 82.13 \\
\hline
\end{tabular}

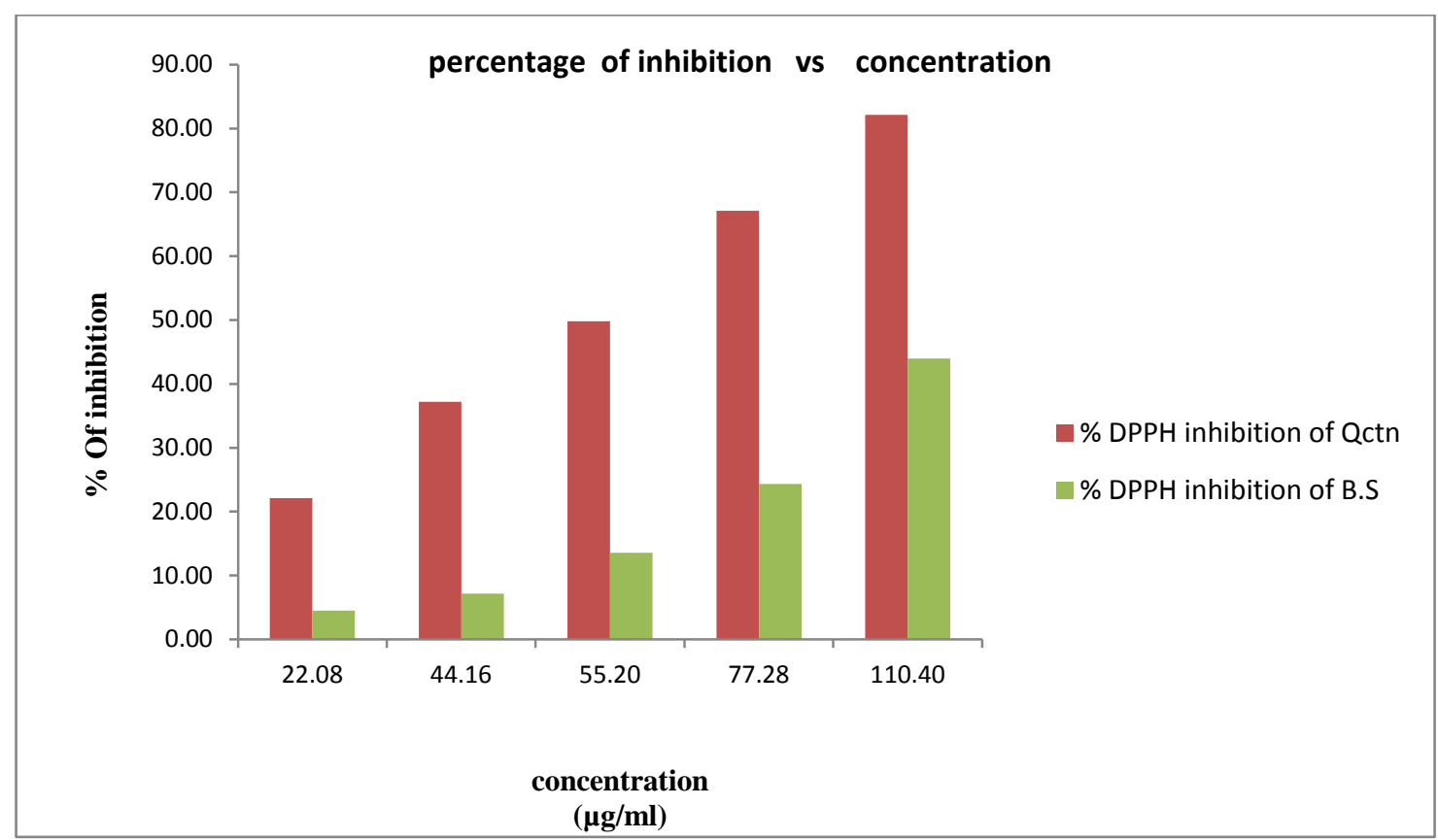

Figure 3: Evaluation of DPPH free-radical scavenging activity of methanolic whole plant extract of B.S. With respect of standard quercetin

This assay is being used widely as a preliminary test which provides information on the reactivity of test compound with a stable free radical since odd electron of DPPH gives strong absorption band at $517 \mathrm{~nm}$ (violet colour) and when it is quenched by the extract, there is a decrease in absorbance. Methanolic whole plant extract of Biophytum sensitivum $L$. showed a very good anti-radical activity in scavenging DPPH radical (comparable to the standard, Quercetin) with a maximum inhibition of about 43.96 at a concentration of $110.46 \mu \mathrm{g} / \mathrm{ml}$.
The reducing capacity of a compound may serve as a significant indicator of its potential antioxidant activity . For the estimation of the reductive ability we investigated the $\mathrm{Fe} 3+$ to $\mathrm{Fe} 2+$ transformation using the method of Oyaizu, where the change in the optical density of the final mixture is measured at $700 \mathrm{~nm}$ (Table-2). Increase in optical density indicates higher reductive ability12, 13. The reducing capabilities of the root extract of $B$. sensitivum $L$. was found to be in dose dependent manner when compared with Quercetin.

Table 5: Reducing ability of methanolic whole plant extract of B.S. With respect to standard Quercetin at $700 \mathrm{~nm}$

\begin{tabular}{|l|c|c|c|}
\hline \multirow{2}{*}{$\begin{array}{l}\text { SL. } \\
\text { NO }\end{array}$} & $\begin{array}{c}\text { CONCENTRATION } \\
(\mu \mathrm{g} / \mathrm{ml})\end{array}$ & B.S. & QUERCETIN \\
\cline { 2 - 4 } & 400 & 0.317 & 2.421 \\
\hline 1. & 600 & 0.538 & 2.548 \\
\hline 2. & 1000 & 0.695 & 2.855 \\
\hline 3. & 2000 & 1.171 & 2.917 \\
\hline 4. & & & \\
\hline
\end{tabular}




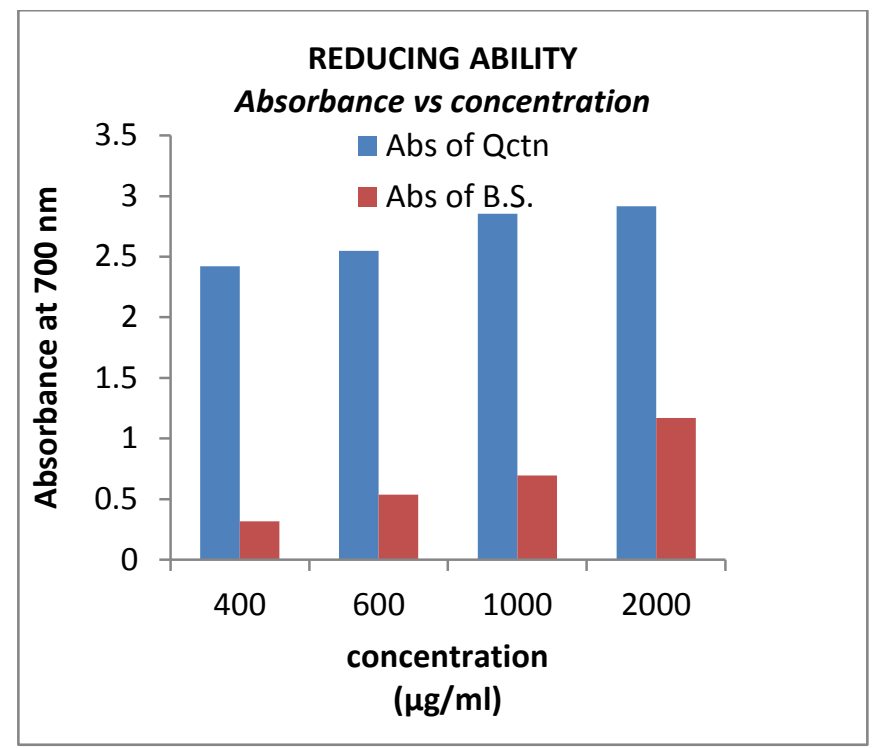

Figure 4: Reducing ability of methanolic whole plant extract of B.S. With respect to standard Quercetin

\section{CONCLUSION:}

The methanolic extract of whole plant extract of $B$. sensitivum L.contains flavonoids, which possess antioxidant property. Hence further investigation and proper isolation of more active principles might help in the findings of new lead compounds which will be effective against free radical mediated diseases.

\section{ACKNOWLEDGEMENT:}

I am very thankful to Mr. Supriya Mana for helping me during my research work.

\section{REFERENCE:}

1. Kamboj, V.P. 2000.Herbal medicine. Current science. Vol.78.3551

2. Pal, S., Shukla, Y. 2003. Herbal medicine: current status and the future. Asian pacific journal of cancer prevention. Vol 4. 281-288.

3. Sharma,A., Shankar.C., Tyagi, L., Singh, M., Rrao,C.2008. Herbal Medicine for Market Potential in India: An Overview. Academic journal of plant sciences. Vol 2. 26-36.

4. Ananda Prabu K, Kumarappan CT, Sunil Christudas, Kalaichelvan VK, Effect of Biophytum sensitivum on streptozotocin and nicotinamideinduced diabetic rats, Asian Pacific Journal of Tropical Biomedicine (2012)31-35

5. V. H. Bhaskar and V. Rajalakshmi, Anti-tumor activity of aqueous extract of Biophytum sensitivum Linn, Annals of Biological Research, 2010, 1 (3) : 76-80

6. D. Natarajan, M.S. Shivakumar, Srinivasan; Antibacterial activity of leaf extract of Biophytum sensitivum, Journal of pharmaceutical sciences and research,2010, 2(11),717-720

7. C Guruvayoorappan, Biophytum sensitivum : Ancient medicine, modern targets,JAPTR, 2012 , 3 (2) , 83-91

8. Shivakumar MS, Srinivasan R, Natarajan D, Bioefficacy of Biophytum sensitivum (L.) leaf extracts against Dengue Mosquito Vector Aedes Aegypti (L.), 2012, RJPBCS, 3 (3), 885-892.

9. Sannigrahi, S., Mazumder, U. K., Pal, D., Mishra. 2009. Hepatoprotective potential of methanol extract of Clerodendrum infortunatum Linn. against CCl4 induced hepatotoxicity in rats. Indian Journal of Experimental Biology. Vol 5( 20).394-399.

10. Pal, D., Sannigrahi, S., Mazumder, U. 2009. Analgesic and anticonvulsant effects of saponin isolated from the leaves of Clerodendrum infortunatum Linn. in mice. Indian Journal of Experimental Biology. Vol.47.743-747

11. Kuluvar,G., Mahmood,R., Mohamed,R., Ahamed,K., Babu,P., Venkatarangaiah, K. 2009 .Wound healing activity of Clerodendrum infortunatum Linn. Root extracts. International Journal of Biomedical and Pharmaceutical Sciences.Vol. 3(1).2125
12. Naskar, S., Mazumder,U., Pramanik,G., Bala, A., Haldar,P., Islam, A., Gupta,M. 2011. Comparative in vitro anti oxidant activity of different parts of Cocos nucifera linn. on reactive oxyzen and nitrogen species. International Journal of Pharmacy and Pharmaceutical Sciences. Vol 3, Suppl 3. 104-107.

13. Kiranmai,M., Kumar,M., Mohammed, I.2011. Comparison of total flavanoid content of Azadirachta indica root bark extracts prepared by different methods of extraction. Research Journal of Pharmaceutical, Biological and Chemical Sciences. Volume 2. 254-261

14. Gupta,A., Naraniwal,M., Kothari,V.2012.Modern extraction methods for preparation of bioactive plant extracts. International Journal of Applied and Natural Sciences (IJANS) .Vol.1, Issue 1. 8-26.

15. Siddique,N.A., Mohd, M., Kalam, A., Mohd, A.2010. Evaluation of antioxidant activity, quantitative estimation of phenols and flavonoids in different parts of Aegle marmelos. African Journal of Plant Science Vol. 4 (1). 001-005,

16. Fernandes,A.,Assunc,M.,Ferreira,A.,Randau,K.P.,DeSouza,T.201 2. Total Flavonoids Content in the RawMaterial and Aqueous Extractives fromBauhinia monandra Kurz (Caesalpiniaceae). The ScientificWorld Journal .Volume 2012.1-7.

17. Lavanya,R., Maheshwari,S., Harish,G., Raj,B., Kamali,S., Hemamalani,D., Varma,J., Reddy,C.2010.In-vitro Antioxidant Activity of Methanolic Extract in Leaves of Anisomeles malabarica Linn. Research Journal of Pharmaceutical, Biological and Chemical Sciences.vol- 1(4).737-744.

18. Kanchan. Chauhan,P.K.,Jaryal,M., Kumari,K., Singh,M. 2012. Phytochemical and invitro anti oxidant potential ofaquous leaf extracts of Brassica juncea and Coriandrum sativum . IJPS.Vol. 3(8). 2862-2865.

19. Aghdam,M.,Dehghan,G., Kafshboran,H.R. 2011. Comparative study of ABTS radical scavenging activity and flavonoid contents in several populations of Teucrium polium. International Conference on Life Science and Technology. vol.3.55-58. 